\title{
HAKIKAT PERCERAIAN BERDASARKAN KETENTUAN HUKUM ISLAM DI INDONESIA
}

\author{
Dahwadin', Enceng Iip Syaripudin², Eva Sofiawati ${ }^{3}$ \\ Muhamad Dani Somantri ${ }^{4}$ \\ Sekolah Tinggi Agama Islam Al-Musaddadiyah Garut ${ }^{123}$ \\ Institut Agama Islam Latifah Mubarokiyah Tasikmalaya ${ }^{4}$ \\ Email :dahwadin@stai-musaddadiyah.ac.id1,Email:Enceng.Iipsyaripudin@stai- \\ musaddadiyah.ac.id², Email: eva.sofiawati@stai-musaddadiyah.ac.id³, \\ Email: muhammaddanisomantri34@gmail.com ${ }^{4}$
}

\begin{abstract}
Divorce in Islamic law is an act or step taken by a husband and wife couple if their household relationship cannot be reunited and if it continues will cause harm to both husband, wife, children, and the environment. So that in Islamic law divorce is done in a good way in order to bring harm to all parties who have an interest. This good way can be realized by looking at the provisions of article 65 of Law No. 7 of 1989 Jo Law No. 3 of 2006 Jo Law No. 50 of 2009 concerning Religious Courts, and Article 115 Compilation of Islamic Law which says that divorce can only be conducted in front of a religious court hearing after the religious court has tried and failed to reconcile the two parties. This is what has then been disseminated in the community evenly in all walks of life so that there is still a violation of the law for people who divorce outside the hearing by religious court judges. This will have a negative impact on the continuity of the life of a husband and wife or their children in the next life. The purpose of this study is to analyze and sharpen the analysis of how the true nature of divorce when viewed based on the provisions of Islamic law in force in Indonesia as one way that this regulation can absorb in all walks of life. Because as we know, some people who are still struggling with tradition when faced with family problems are not done before a religious court hearing. This research method leads to the study of literature (library research), referring to the theory of the application of law, the purpose of law, legal development, law enforcement and law enforcement in Indonesia in creating justice, usefulness, order, and peace in society.
\end{abstract}

Keywords: Divorce, Islamic Law, Indonesia

\begin{abstract}
Abstrak
Perceraian dalam hukum Islam merupakan perbuatan atau langkah yang dilakukan oleh pasangan suami dan isteri apabila hubungan rumah tangga nya tidak dapat dipersatukan kembali dan apabila diteruskan akan menimbulkan madharat baik bagi suami, isteri, anak, maupun lingkungan nya. Sehingga dalam hukum Islam perceraian ini dilakukan dilakukan dengan cara yang baik demi mewujudkan kemasllahatan bagi semua pihak yang memiliki kepentingan. Cara yang baik ini dapat terealisasikan dengan melihat ketentuan Pasal 65 UU No. 7 Tahun 1989 Jo UU No. 3 Tahun 2006 Jo UU No. 50 Tahun 2009 tentang Peradilan
\end{abstract}


Dahwadin, et al.

Agama, dan Kompilasi Hukum Islam Pasal 115 yang mengatakan bahwa perceraian hanya dapat dilakukan di depan sidang Pengadilan Agama setelah Pengadilan Agama berusaha dan tidak berhasil medamaikan kedua belah pihak. Hal inilah yang kemudian dimasyarakat belum tersosialisasikan secara merata di semua lapisan masyarakat sehingga masih terjadi pelanggaran hukum bagi masyarakat yang melakukan perceraian di luar sidang oleh hakim pengadilan agama. Hal ini akan mengakibatkan dampak buruk bagi keberlangsungan kehidupan suami isteri ataupun anak nya di kehidupan selanjutnya. Tujuan penelitian ini adalah untuk menganalisa dan mempertajam analisis bagimana hakikat sebenarnya terhadap perceraian apabila dilihat berdasarkan ketentuan hukum Islam yang berlaku di Indonesia sebagai salah satu cara agar peraturan ini dapat menyerap di semua lapisan masyarakat. Karena sebagaimana kita ketahui sebagian masyarakat yang masih bergelut dengan tradisi ketika dihadapkan pada permasalahan keluarga tidak dilakukan di depan sidang pengadilan agama. Metode penelitian ini mengarah kepada kajian secara kepustakaan (library research), mengacu kepada teori penerapan hukum, tujuan hukum, pembangunan hukum, keberlakuan hukum dan penegakan hukum di Indonesia dalam menciptakan keadilan, kemanfaatan, ketertiban, dan ketentraman di masyarakat.

Kata Kunci : Perceraian, Hukum Islam, Indonesia.

\section{PENDAHULUAN}

Hukum Islam diturunkan oleh Allah SWT bertujuan untuk mencegah kerusakan pada manusia dan mendatangkan kemaslahatan bagi mereka, mengarahkan kepada kebenaran, keadilan dan kebijakan serta menerangkan jalan yang harus dilaluinya. Dalam hal ini bertumpu pada lima prioritas utama yang disebut sebagai maqasid asy-syari'ah yakni memelihara agama, jiwa, akal, keturunan dan harta benda dengan berlandaskan Al Qur'an yang bersifat universal dan dinamis. Dengan kata lain tujuan disyari'atkannya Islam adalah untuk kemaslahatan hidup manusia baik rohani maupun jasmani, individual maupun kelompok (Sadiani, 2016: 143). Perkawinan dinyatakan putus apabila salah satu pihak meninggal dunia atau bila terjadi perceraian. Alasan-alasan bagi perceraian tidak sama di semua daerah, namun pada umumnya alasanalasan perceraian adalah : tidak mempunyai anak, cacat badan, berzinah, penganiyaan, perselisihan baik antara suami istri ataupun antara kerabat yang bersangkutan, dan tidak memberi nafkah (Syahuri, 2013: 67). Dalam definisnya perkawinan ialah akad yang mmenghalalkan pergaulan antara seorang laki-laki dan seorang perempuan karena ikatan suami (Nurpaiz et al., 2020: 2).

Hidup bahagia, sejahtera bahagia, dan tentram antara pasangan suami dan istri yang terikat dalam satu perkawinan yang sah menjadi dambaan bagi setiap insan dimuka bumi. Manusia pada hakikatnya 
memerlukan perkawinan guna untuk memenuhi kebutuhan biologis baik dari pihak laki-laki maupun perempuan (Somantri, Dahwadin, 2018: 204). Undang-undang perkawinan tidak melarang perceraian jika seandainya memang benar-benar tidak dapat dihindarkan, itu pun harus dilaksanakan dengan secara baik di hadapan sidang pengadilan. Perceraian yang demikian ini merupakan hal baru dalam masyarakat Indonesia, yang sebelumnya hak cerai sepenuhnya berada di tangan suami yang pelaksanaannya dapat dilakukan secara semaunya. Pelaksanaan yang seperti ini sungguh sangat memperihatinkan pihak istri, biasanya pihak suami setelah menceraikan istrinya sama sekali tidak memerhatikan hak-hak istri dan anak-anaknya (Manan, 2008: 9).

Putusnya hubungan perkawinan karena perceraian adalah putusnya ikatan perkawinan sebab dinyatakan talak oleh seorang suami terhadap istrinya yang perkawinannya dilangsungkan menurut agama Islam, yang dapat pula disebut dengan cerai talak. Cerai talak ini selain diperuntukan bagi seorang suami yang telah melangsungkan perkawinan menurut agama Islam yang akan menceraikan istrinya, juga dapat dimanfaatkan oleh istri jika suami melanggar perjanjian taklik talak. Dalam Pasal 39 Undang-Undang tentang Perkawinan menyatkan bahwa: (1) perceraian hanya dapat dilakukan di depan sidang pengadilan setelah pengadilan yang bersangkutan berusaha dan tidak berhasil mendamaikan kedua belah pihak. (2) untuk melakukan perceraian itu harus ada cukup alasan, bahwa antara suami istri itu tidak akan dapat hidup rukun sebagai suami istri. Ini berarti Undang-Undang tentang Perkawinan menganut prinsip untuk mempersukar terjadinya perceraian. Untuk memungkinkan perceraian harus ada alasan-alasan tertentu serta harus dilakukan di depan sidang pengadilan. Prinsip yang demikian ini sejalan dengan tujuan perkawinan untuk membentuk kelarga yang bahagia, kekal, dan sejahtera berdasarkan Ketuhanan Yang Maha Esa (Usman, 2006: 400).

Ketentuan ini diadakan karena dalam kenyataannya di masyarakat, suatu perkawinan banyak yang berakhir dengan perceraian dan tampaknya hal ini terjadi dengan cara yang mudah. Bahkan adakalanya banyak terjadi perceraian itun karena perbuatan sewenang-wenang dari pihak laki-laki. Sebaliknya, dalam hal seorang istri yang merasa terpaksa untuk bercerai dengan suaminya, tidak semudah seperti yang dapat dilakukan oleh seorang suami terhadap istrinya, sehingga sering pula terjadi seorang istri masih berstatus sebagai istri tetapi kenyataannya tidak merasakan lagi dirinya sebagaimana layaknya seorang istri. Berhubungan karena itu, terutama kaum wanita, hal tersebut tentulah merupakan suatu hal yang tidak menyenangkan maka timbul suara-suara yang menghendaki supaya diadakan suatu peraturan perundang-undangan yang mengaturnya, terutama untuk membatasi kewenang-wenangan pihak laki-laki tersebut (Usman, 2006: 400). 
Perceraian di luar pengadilan di sebagian masyarakat sudah menjadi hal yang terbiasa dilakukan ketika terjadi perselisihan antara ke duanya, berangkat dari pemahaman bahwa ke tidak tahuan masyarakat akan adanya hukum yang mengatur tentang kehidupan keluarga di salah satu lembaga khusus untuk menangani persengketaan yang timbul dari keluarga, salah satunya yaitu mengatur tentang pasca terjadinya perkawinan kemudian timbul perselisihan selama perkawinan berlangsung yang berujung pada perceraian. Kemudian apabila dilihat dari berbagai aspek terhadap akibat mengenai hukum perceraian di luar pengadilan akan berimbas kepada keluarga itu sendiri. Diantaranya ialah status dari ke dua belah pihak di mata hukum yang khusus mengatur hal ini, dan kemudian ketika salah satunya akan melaksanakan pernikahan kembali maka proses yang akan ditempuh nya pun akan semakin rumit yaitu harus melalui proses di peradilan di wilayah hukum tempat masingmasing.

Perceraian di depan sidang Pengadilan Agama sebagaimana terdapat dalam ketetapan Pasal 65 Undang-Undang No. 7 Tahun 1989 jo Undang-Undang No. 3 Tahun 2006 tentang Peradilan Agama dan Pasal 115 Kompilasi Hukum Islam menjadi satu keharusan dan kewajiban yang harus dilakukan oleh keluarga atau pasangan yang memiliki masalah keharmonisan antara keluarganya. Institusi peradilan agama ini merupakan peradilan khusus untuk orang-orang yang beragama Islam (Pasal 1 (1), Pasal 2, dan Pasal 49 (1)). Maslahat ini dapat terpeliharanya agama (hifdz al din), harta (hifdz al mal), jiwa (hifdzl al nafs), akal (hifdzl al $a q l$ ), dan keturunan (hifdzl al nasab). Apabila terjadi perbenturan antara maslahat dan madharat maka nilai kandungan kemaslahatan yang lebih besar harus diutamakan. Hal ini sesuai dengan qaidah bahwa :

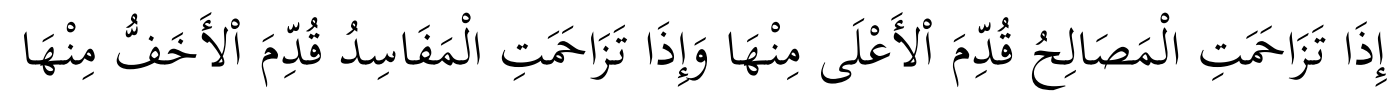

Ártinya : "Jika ada beberapa kemaslahatan berbenturan, maka maslahat yang lebih besar (lebih tinggi) harus didahulukan. Dan jika ada beberapa mafsadah (bahaya, kerusakan) bertabrakan, maka yang dipilih adalah mafsadah yang paling ringan".

Keharusan perceraian di depan pengadilan agama ini semata-mata untuk mewujudkan kehidupan suasana damai, aman, tertib, dan sejahtera. Sehingga hakim pengadilan agama dalam menerima, memeriksa, memutus, dan menyelesaikan perkaranya dapat mewujudkan kembali pasangan sakinah, mawaddah, dan rahmah, terhadap pasangan yang berselisih. Karena pada dasarnya pernikahan merupakan asas pokok hidup yang paling utama dalam pergaulan atau masyarakat yang sempurna (Dahwadin et al., 2018: 10). 


\section{METODE PENELITIAN}

Metode penelitian yang digunakan dalam penelitian ini adalah dengan metode yuridis normatif melalui pendekatan analisis, dengan teknik pengumpulan data. Pengumpulan data dapat dilakukan dalam berbagai setting, berbagai sumber, dan berbagai cara (Sugiyono, 2014: 137). Setiap manusia memiliki kecenderungan untuk melihat apa yang ingin dilihat, mendengar apa yang ingin didengarkan, dan melakukan apa yang menjadi keinginannya. Anggapan dasar ini sering menganggu peneliti sebagai manusia di dalam mengadakan pengamatan. (Suharismi, 2013: 265). Pengumpulan data dimulai dengan menganalisis ketentuan normative yang sesuai dengan pengambilan teori dalam penulisan ini ialah tujuan hukum, pembangunan hukum, penegakan hukum, dan keberlakuan hukum. sehingga ketentuan terhadap perceraian harus dilakukan di depan sidang pengadilan agama tersampaikan secara sistematis melalui pendekatan berbagai ketentuan hukum Islam di Indonesia. Selain itu dalam membahas dan menulis dalam penulisan ini mengambil dari berbagai telaah pustaka yang sudah dipublikasi, baik berupa buku, jurnal, artikel, maupun di dalam website internet.

Sumber data dalam penulisan ini terdiri dari data primer dan data sekunder. Data primer berisikan tentang ketentuan-ketentuan normatif yakni Undang-Undang No. 1 Tahun 1974 Pasal 39 tentang perkawinan. Peraturan Pemeritah No. 9 Tahun 1975 Pasal 18 tentang Pelaksanaan Undang-Undang No. 1 Tahun 1974 tentang Perkawinan. Undang-Undang No. 7 Tahun 1989 Pasal 65 tentang Peradilan Agama, dan Kompilasi Hukum Islam (KHI) Pasal 115. Data sekunder yang digunakan berupa ketentuan Peraturan Perundang-Undangan, yakni Undang-Undang Nomor 7 Tahun 1989. Undang-Undang No. 1 Tahun 1974. Peraturan Pemerintah No. 9 Tahun 1975, dan Kompilasi Hukum Islam (KHI). Analisis data dilakukan berdasarkan ketentuan metode pengumpulan data melalui pendekatan analisis berdasarkan kajian normative melalui berbagai ketentuan yang mengharuskan perceraian dilakukan di depan sidang pengadilan agama sebagaimana telah dijelaskan dan disebutkan di atas. Undang-Undang No. 1 Tahun 1974 tentang Perkawinan merupakan sumber hukum perkawinan dan hukum keluarga Islam yang mengatur secara lengkap dan modern tentang perkawinan dan perceraian umat Islam yang berakar pada agama Islam (Dahwadin et al., 2018: 10). 
Dahwadin, et al.

\section{PEMBAHASAN}

Pada dasarnya Islam menghendaki setiap perkawinan berlangsung selama-lamanya, sehingga merupakan pasangan suami isteri yang dapat bersama-sama mengatur rumah tangga dan mendidik anaknya dengan baik. Tanpa dasar-dasar pembinaan orang tua terhadap kehidupan anak kemungkinan akan dapat menghancurkan kehidupan umat manusia dan bahkan kebudayaan setiap bangsa. Karena itu setiap orang tua di dalam kehidupan rumah tangga akan dapat dilihat dari hasilnya yang ditunjukan oleh seorang anak dalam pergaulan sehari-hari (Djamal, 1992: 93).

Perkawinan merupakan aspek hukum dan menyangkut perbuatan hukum, maka tentu saja tidak semua dan selamanya perkawinan itu dapat berlangsung secara langsung atau abadi. Tidak sedikit kenyataan terjadi di sekitar kita memperlihatkan contoh rapuhnya sendi-sendi suatu perkawinan yang tidak jarang berakibat pada timbulnya suatu perceraian dengan segala konsekuensinya dan aksesnya yang timbul. Karena perkawinan menyangkut perbuatan hukum maka dengan sendirinya dalam perceraian terkait pula perbuatan hukum, yang berarti bahwa ada suatu tantangan normatif yang terkait di dalam suatu perceraian (Konoras, 2014: 55). Kendati di dalam Al-Qur'an tidak terdapat ayat-ayat yang menyuruh atau melarang eksistensi perceraian itu, sedangkan untuk perkawinan ditemukan beberapa ayat yang menyuruh melakukan nya. Walaupun banyak ayat Al-Qur'an yang mengatur thalaq, namun isinya hanya sekedar mengatur bila thalaq mesti terjadi, meskipun dalam bentuk suruhan atau larangan. Kalau mau menthalaq seharusnya sewaktu istri itu berada dalam keadaan yang siap untuk memasuki masa iddah, seperti terdapat di dalam beberapa ayat Al-Qur'an diantaranya :

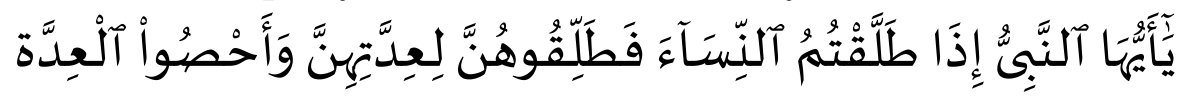

Artinya : "Hai Nabi, apabila kamu menceraikan isteri-isterimu Maka hendaklah kamu ceraikan mereka pada waktu mereka dapat (menghadapi) iddahnya yang wajar" (QS. Thalaq : 1).

Demikian pula dalam bentuk melarang, seperti firman Allah, yaitu

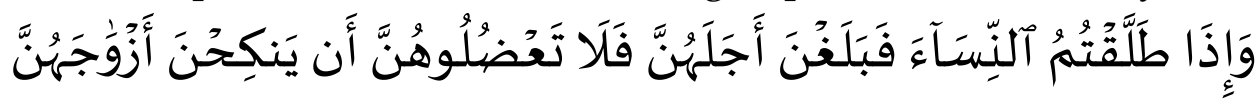

Artinya : "Apabila kamu mentalak isteri-isterimu, lalu habis masa iddahnya, Maka janganlah kamu (para wali) menghalangi mereka kawin lagi dengan bakal suaminya" (QS. Al Baqarah : 232).

Dari ketentuan ayat di atas, bahwa perceraian itu halal dilakukan tetapi sangat dibenci oleh Allah SWT. Sebagaimana tertuang dalam hadits sebagai berikut (Rasjid, 2012: 401-402): 


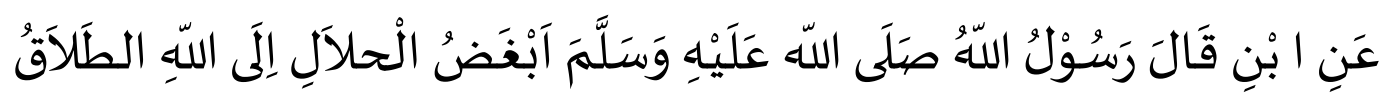

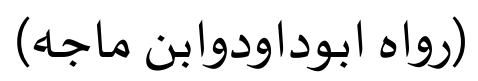

"Dari Ibnu Umar. Ia berkata bahwa Rasulullah SAW, telah bersabda "sesuatu yang halal yang amat dibenci Allah ialah talak". (Riwayat Abu Daud dan Ibnu Majah).

Talak tidak boleh lagi dijatuhkan sesuka hati kaum laki-laki di atas penderitaan kaum perempuan, akan tetapi harus memiliki alasan-alasan yang kuat dan disampaikan di muka sidang pengadilan. Itu pun setelah pengadilan lebih dahulu berusaha mendamaikan pasangan suami istri tetapi tidak berhasil. Dari pada mempertahankan kehidupan keluarga yang terus menerus tidak harmonis, maka akan lebih baik mengakhiri kehidupan keluarga itu dengan cara yang lebih baik dan lebih terhormat. Disinilah terletak arti penting dari kalam allah :" fa-imsakun-bima'rufin au tasrihun-biihsan, mempertahankan rumah tangga dengan cara yang baik, atau (kalau terpaksa) melepaskannya dengan cara yang baik pula (Summa, 2004: 178).

\section{Perceraian Menurut Undang-Undang Nomor 1 Tahun 1974}

Masalah putusnya perkawinan, Undang-Undang Nomor 1 Tahun 1974 mengaturnya dalam Bab VIII Pasal 38 sampai Pasal 41 Tahun 1975 Pasal 14 sampai dengan Pasal 36, dan hal-hal teknis lainnya dalam Peraturan Menteri Agama Nomor 3 Tahun 1975. Ketentuan Pasal 38 UU No 1 Tahun 1974 menyebutkan suatu perkawinan dapat putus karena tiga hal, yaitu kematian salah satu pihak, perceraian, dan atas putusan hakim. Selanjutnya dalam Pasal 39 ayat (1), (2) dan (3), disebutkan pula bahwa perceraian hanya dapat dilakukan di depan sidang Pengadilan setelah pengadilan (Majelis Hakim) tidak berhasil mendamaikan ke dua belah pihak, serta cukup alasan bagi mereka untuk bercerai karena tidak ada harapan lagi untuk hidup rukun dalam suatu rumah tangga, perkawinan mereka betul-betul sudah pecah. Gugatan perceraian dapat diajukan oleh pihak suami atau pihak istri dengan alasan yang telah ditentukan oleh peraturan perundang-undangan yang berlaku (Tutik, 2008: 133).

Undang-Undang Nomor 1 Tahun 1974 tentang Perkawinan merupakan sumber hukum perkawinan dan hukum keluarga Islam yang mengatur secara lengkap dan modern tentang perkawinan dan perceraian umat Islam yang berakar pada agama Islam. sebenarnya Undang-undang ini jauh lebih sempurna dan lengkap mengenai substansi yang diatur di dalamnya, baik sempurna dan lengkap mengenai substansi yang diatur di dalamnya, baik berupa asas-asas maupun norma-norma hukum perkawinan dan perceraian serta kehidupan berkeluarga. Akan tetapi, dalam realitas keberlakuannya dalam masyarakat Muslim sendiri di 
Dahwadin, et al.

Indonesia akhir-akhir ini, sangat mudah terjadi perkawinan, demikian juga perceraian sehingga timbul kesan bahwa perkawinan itu bertujuan untuk cerai. Bahkan, pelanggaran Undang-undang perkawinan dalam bentuk perkawinan atau perceraian di bawah tangan yang lepas dari pengawasan dan pencatatan pejabat pencatat perkawinan dan perceraian (Muhammad, 2010: 68).

Perbuatan pelanggaran tersebut perlu menjadi fokus kajian untuk diketahui motivasi, alasan, dan tujuannya sehingga dapat dicari solusi yang tepat untuk diatasi atau dicegah terjadinya pelanggaran yang berdampak luas bagi kehidupan berbangsa dan bernegara. Dampak tersebut, antara lain, berupa pengacauan administrasi kependudukan, status kewarganegaraan, perlindungan istri dan anak, serta harta kekayaan mereka. Hal ini akan menjadi masalah dalam kehidupan rumah tangga dan keluarga, baik selama perkawinan maupun jika terjadi percerian suami istri.

Pada beberapa kelemahan tersebut di atas, Undang-Undang Nomor 1 Tahun 1974 mengatur beberapa asas yang dapat berfungsi sebagai penghambat dan mengatur sedemikian rupa dalam pasalpasalnya guna mencegah terjadinya pelanggaran, baik terhadap asas-asas maupun terhadap norma-norma yang terjelma dalam rumusan pasalpasal Undang-Undang Perkawinan. Asas-asas dimaksud antara lain, asas suka dibatasi dengan ketat, asas kematangan calon mempelai, asas perbaikan derajat kaum wanita, dan asas keharusan pencatatn perkawinan dan perceraian dengan ancaman hukuman bagi pelanggarnya, baik calon mempelai maupun pejabat pencatat perkawinan dan perceraian (Muhammad, 2010: 68-69).

Suatu norma dianggap sah sebagai norma hukum (legal norm) yang mengikat untuk umum apabila norma hukum itu berlaku karena diberlakukan atau karena dianggap oleh para subjek hukum yang diikatnya. Keberlakuan ini dalam bahasa Inggris validity dalam bahasa Jerman geltung atau dalam bahasa Belanda gelding. Keabsahan berlakunya atau keberlakuan suatu Undang-undang atau peraturan perundangundangan itu sendiri pada pokoknya ditentukan oleh banyak faktor dan beraneka cara pandang. Secara umum dapat dikemukakan adanya empat kemungkinan faktor yang menyebabkan norma hukum dalam Undangundang atau peraturan perundang-undangan dikatakan berlaku. Normanorma hukum dimaksud dapat dianggap berlaku karena pertimbangan yang bersifat filosofis, yuridis, sosiologis, politis, maupun secara administratif (Asshiddiqie, 2010: 166).

Islam mengehndaki suatu kelanggengan hidup berumah tangga tidak menutup kemungkinan nyata bahwa hidup dan kehidupn manusia itu tidak langgeng dan ada kalanya menemui suatu kegagalan. Sebagai sebab timbulnya kegagalan berumah tangga tentu banyak sekali, bahkan 
kadang-kadang kalau kehidupan suami istri dipaksakan terus dalam suatu kehidupan yang tidak harmonis niscaya aka nada kemungkinan lain yang timbul sebagai akibat dari kegagalan individu. Karena itu Islam masih memberikan kesempatan dan mengizinkan pembubaran perkawinan, kecuali salah satu pihak meninggal dunia, dengan alasanalasan yang dapat dibenarkan, pembubaran (putusnya) perkawinan dengan sebab-sebab yang dapat dibenarkan itu dapat terjadi dalam dua peristiwa (Sabiq, 1990: 93-94) :

a. Kematian salah satu pihak.

b. Putus akibat perceraian, karena adanya :

1) Talak atas inisiatif suami;

2) Khuluk, yaitu perceraian atas inisitaif istri agar suami mau menceraikan dengan baik-baik dan mendapat ganti rugi atau tebusan (iwadl);

3) Fasakh, yaitu putusnya perkawinan atas keputusan hakim Pengadilan Agama, karena dinilai perkawinan itu tidak memenuhi syarat-syarat atau rukun-rukunnya baik disengaja maupun tidak disengaja;

4) Syiqoq, yaitu konflik antara suami istri yang tidak dapat didamaikan lagi;

5) Melanggar taklik talak, yaitu pelanggaran janji yang telah diucapkan sesaat setelah akad nikah.

Putusnya perkawinan menurut Undang-Undang No 1 Tahun 1974 karena tiga hal, pertama, karena kematian, kedua, karena perceraian, dan ketiga, karena putusan pengadilan (Pasal 38 huruf a, b, dan c). Sedangkan Peraturan Pemerintah No 9 Tahun 1975 menggunakan istilah dengan cerai talak, untuk perceraian. Adapun perceraian karena putusan pengadilan (Pasal 38 huruf c) Peraturan Pemerintah No 9 Tahun 1975 menggunakan istilah cerai gugatan. Perbedaan antara perceraian atau cerai talak dengan karena putusan pengadilan adalah perceraian ikrar suami di depan sidang pengadilan, sedangkan putusnya perkawinan karena putusan pengadilan atau dalam istilah Peraturan Pemerintah No 9 Tahun 1975 cerai gugatan adalah perceraian yang terjadi karena gugatan salah satu pihak dari suami istri tersebut, atau suatu perceraian akibat putusan pengadilan (Hakim, 2000: 167-168).

Oleh karena itu, tugas hakim dalam menangani perceraian adalah berusaha untuk mendamaikan kedua belah pihak, bila dipandang perlu, dapat meminta bantuan orang atau lembaga penasehat semacam BP 4 . Usaha untuk mendamaikan itu harus dilakukan setiap kali sidang (Pasal 31 ayat (1) dan (2) Peraturan Pemerintah No 9 1975). Apabila usaha perdamaian itu berhasil dan kedua pihak dapat rukun kembali dan di lain waktu terjadi permohonan cerai, maka alasan yang sama tidak dapat diajukan kembali sebagai gugatan yang baru (Pasal 32 Peraturan 
Dahwadin, et al.

Pemerintah No. 9 Tahun 1975). Hakim yang beragama Islam akan mendapat murka Allah apabila ia mempermudah perceraian, sebab perceraian sangat dibenci oleh Allah (Hakim, 2000: 167). Selain Undangundang No 1 Tahun 1974 tentang perkawinan, pemerintah mengeluarkan Peraturan Pemerintah Nomor 9 Tahun 1975, Peraturan Menteri Agama Nomor 3 Tahun 1975 dan peraturan lainnya sebagai pedoman pelaksanaan Undang-Undang No 1 Tahun 1974. Mengenai pengertian cerai dan talak, diadakan perbedaan yaitu (Anwar, 1988: 174) :

a. Kalau Talak, ialah perceraian atas kehendak suami isteri yang diikrarkan oleh suami di depan sidang Pengadilan Agama.

b. Kalau cerai, ialah perceraian yang diputuskan oleh sidang Pengadilan Agama atas rafa/pengaduan si isteri yang ditinggalkan oleh suaminya dan sebagainya".

Dengan demikian, jelaslah bahwa aturan yang ditetapkan untuk thalaq adalah aturan bagus dan mulia yang jikalau diikuti, maka akan baiklah semuanya, karena dia tidak mewajibkan suami untuk menetap bersama istrinya apabila terjadi pertengkaran hebat disebabkan perbuatan keduannya dan tidak menjadikan masalah perceraian sesuatu yang mudah tanpa tanggungan (Bek, 2009: 99-100). Dalam penulisan ini, penulis menggambarkan terhadap hakikat perceraian yang sesungguhnya yang sesuai dengan ketentuan hukum Islam di Indonesia, yakni dapat digambarkan sebagai berikut:

Gambar 0.1 : Skema Kerangka Penelitian

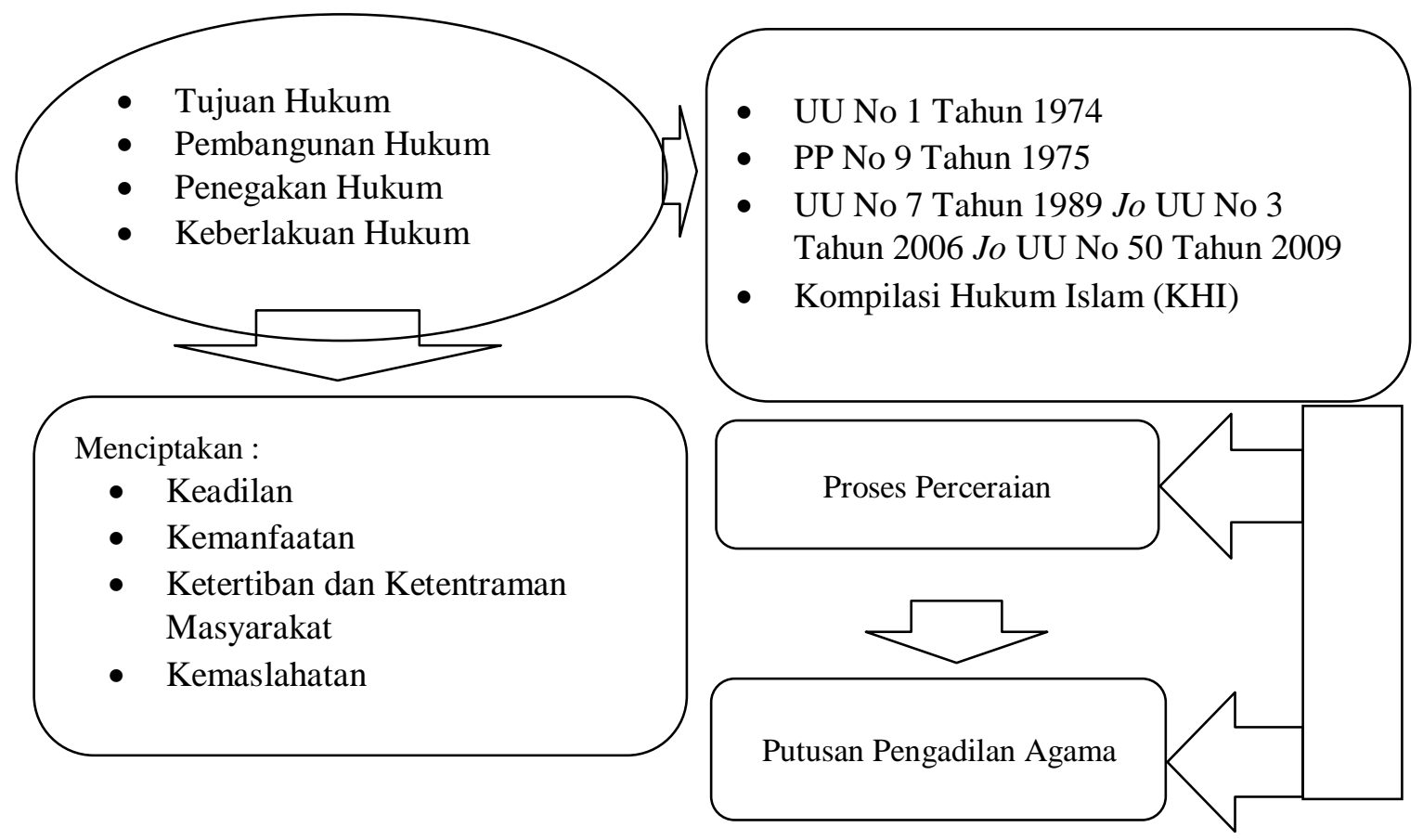


Kebahagiaan rumah tangga yang selama perkawinannya rukun dan damai selama ini, kemudian setelah muncul masalah dan tidak diselesaikan dengan tuntas melalui jalur hukum yang idealnya. Sebab para pihak, baik pihak suami atau istri memandang sesuatu masalah itu tidak perlu melibatkan institusi pengadilan dan tidak memproses melalui jalur aturan Perundang-undangan yang ada. Akhirnya, dikemudian hari akan berakibat fatal dalam kehidupan masing-masing akan menimbulkan penyesalan yang signifikan. (Siregar, 2015: 167-168).

Perceraian yang berbunyi bahwa sebuah perceraian hanya dapat dilakukan didepan sidang Pengadilan Agama dimana setelah hakim berusaha dan tidak berhasil mendamaikan kedua belah pihak (KHI Pasal 115), Pasal 123 KHI menyebutkan perceraian terhitung pada saat perceraian dinyatakan didepan sidang pengadilan. Pasal 129 'seorang suami yang akan menjatuhkan talak kepada istrinya mengajukan permohonan baik lisan maupun tertulis kepada Pengadilan Agama yang mewilayahi tempat tingga isteri disertai dengan alas an serta meminta agar diadakan sidang untuk keperluan itu (Mohsi, 2015: 237-238).

\section{Perceraian Menurut Pandangan Ulama}

Para ulama dahulu maupun sekarang selalu menerangkan sifat talak dengan sunnat dan bid'ah. Mengenai arti keduanya ada dua istilah yaitu pertama, yang sunnah ialah yang tidak haram menjatuhkannya. Sedangkan yang bid'ah ialah yang haram menjatuhkkannya, dan berdasarkan yang pertama ini tidak ada pembagian lagi selain yang dua tersebut. Kedua, ialah apa yang sudah dikenal ramai, yang dipergunakan pengarang disini, yaitu bahwa talak yang sunnat ialah mentalak isteri yang sudah dicampuri tetapi tidak hamil, bukan isteri yang masih kecil, dan bukan isteri yang sudah tidak haidh lagi. Sedangkan yang bid'ah ialah mentalak isteri yang sedang dalam haidh atau nifas, atau dalam keadaan suci yang telah dicampurinya dan tidak terang hamilnya (Husaini, 1993: 183-184).

Sedangkan terhadap kebolehan seorang hakim menjatuhkan talak kepada istri para ulama berbeda pendapat mengenai hal ini, perbedaan tersebut ialah Abu Hanifah mengatakan bahwa hakim tidak punya hak untuk menjatuhkan talak kepada wanita, apapun alasannya, kecuali suami wanita tersebut impoten, zakarnya terputus, dan pecah atau hilang buah zakarnya. Adapun tidak member nafkah, hilang tak tentu kabar beritanya, dihukum seumur hidup, dan lain-lain, maka hakim tidak boleh menjatuhkan talak terhadap seorang wanita karena hal-hal di atas tanpa perkenan suaminya, sebab talak adalah hak pengendali (suami) (Mughniyah, 2011: 490-491). 
Maliki, Syafi'i dan Ahmad bin Hambali memperbolehkan seorang wanita menuntut talak dari hakim karena adanya sebab-sebab berikut (Mughniyah, 2011: 490-491):

1) Tidak diberi nafkah. Ketiga ulama Mazhab tersebut sepakat bahwa, apabila seorang suami terbukti tidak mampu memberi nafkah pokok kepada istrinya, maka istrinya itu boleh mengajukan tuntutan cerai. Tetapi bila ketidakmampuan itu tidak terbukti, dan si suami tidak mau member nafkah, maka Syafi'i mengatakan bahwa, suami istri tidak boleh diceraikan. Sementara itu, Imam Malik dan Imam Ahmad bin Hambal mengatakan suami istri tidak diceraikan, lantaran tidak adanya nafkah bagi istri sama artinya dengan ketidakmampuan suami member nafkah. Perundang-undangan syara' Mesir menentukan kebolehan menceraikan istrinya dari suaminya karena tidak dipebolehkan nafkah oleh istri.

2) Istri merasa terancam, baik berupa ucapan maupun perbuatan suami. Dalam Al Ahwal Al-Syakhsiyyah-nya, halaman 358, Abu Zahra mengatakan bahwa,"Perundang-undangan Mesir, pasal 25 Tahun 1929 menjelaskan bahwa apabila seorang istri mengaku diancam oleh suaminya yang menyebabkan dia tidak bisa mempertahankan kehidupan rumah tangga bersama orang seperti itu, kalau pengakuan wanita tersebut terbukti, dan hakim tidak mampu mendamaikan keduanya, maka dia dapat menjatuhkan talak kepada wanita tersebut dengan talak ba'in. Akan tetapi, bila si wanita tidak mampu membuktikan pengakuannya tersebut, namun keluh kesahnya berulang-ulang dia sampaikan kepada hakim, maka hakim harus mengirim dua orang juru damai (hakam) dari pihak suami istri (masing-masing seorang) untuk mengetahui sebab-sebab terjadi sengketa keluarga tersebut. Kedua hakam ini harus berusaha sekuat mungkin untuk mendamaikan suami istri itu. Kalau usaha tersebut tidak berhasil, harus diteliti dari mana datangnya kesulitan tersebut. Kalau kesulitan itu bersumber dari pihak laki-laki atau kedua belah pihak, maka kedua hakam itu memutuskan talak ba'in bagi sang istri yang keputusannya diberikan oleh hakim. Perundang-undangan Mesir mengambil ketentuan ini dari Mazhab Maliki dan Ahmad bin Hambal.

3) Terancamnya kehidupan istri karena suami tidak berada ditempat menurut Maliki dan Ahmad bin Hambal, sekalipun si suami meninggalkan nafkah yang cukup untuk selama masa ketidak hadirannya. Bagi Imam Ahmad, jarak minimal sang istri boleh mengajukan gugatan cerai adalah enam bulan sejak kepergian suaminya, dan tiga tahun menurut Maliki (menurut pendapatnya yang lain satu tahun), serta satu tahun menurut perundang-undangan Mesir. Betapapun, hakim tidak berhak menceraikan mereka kecuali bila sang suami menolak pulang atau mengajak istrinya ke tempat dia 
berada. Selanjutnya, Imam Malik tidak membuat perbedaan antara kepergian suami meninggalkan istrinya dengan alasan atau tanpa alasan. Kedua hal tersebut menjadikan adanya perceraian. Sementara itu Mazhab Hambali mengatakan suami istri tidak boleh diceraikan kecuali bila kepergiannya itu tanpa alasan yang jelas.

4) Istri terancam kehidupannya karena suami berada dalam penjara. Ini dikatakan oleh Ibnu Taimiah yang bermazhab Hambali.selama itu perundang-undangan Mesir menyatakan kebolehan cerai bila suami dihukum tiga tahun atau lebih. Dalam kasus yang disebut terakhir ini, istri berhak mengajukan gugatan cerai karena adanya ancaman terhadap kehidupannya sesudah satu tahun suaminya dipenjarakan, dan hakimlah yang menjatuhkan talaknya.

Islam datang dengan seperangkat norma syara yang mengatur kehidupan muamalah yang harus dipatuhi umat Islam sebagai konsekuensi dari keimannya kepada Allah dan Rasul-Nya. Sebagian dari adat lama itu ada yang selaras dan ada yang bertentangan dengan hukum syara yang datang kemudian. Adat yang bertentangan itu dengan sendirinya tidak mungkin dilaksanakan oleh umat Islam secara bersamaan dengan hukum syara. Pertemuan antara adat dan syari'at tersebut terjadilah perbenturan, penyerapan, dan pembauran antara keduanya. Dalam hal ini yang diutamakan adalah proses penyeleksian adat yang dipandang masih diperlukan untuk dilaksanakan. Adapun yang dijadikan pedoman dalam menyeleksi adat lama itu adalah kemaslahatan menurut wahyu. Berdasarkan hasil seleksi tersebut, adat dapat dibagi kepada 4 (empat) kelompok sebagai berikut (Syarifudin, 2008: 393-394):

1) Adat yang lama secara substansial dan dalam hal pelaksanaannya mengandung unsur kemaslahatan. Maksudnya dalam perbuatan itu terdapat unsur manfaat dan tidak ada unsur mudaratnya, atau unsur manfaatnya lebih besar dari unsur mudaratnya. Adat dalam bentuk ini diterima sepenuhnya dalam hukum Islam. Umpamanya uang tebusan darah (diyat) yang harus dibayar oleh pihak pelaku pembunuhan kepada pihak keluarga yang terbunuh. Hukum ini berlaku di kalangan masyarakat Arab sebelum Islam datang dan dinilai dapat terus diberlakukan, hingga ditetapkan menjadi hukum Islam.

2) Adat lama yang pada prinsipnya secara substansial mengandung unsur maslahat (tidak mengandung unsur mafsadat atau mudarat), namun dalam pelaksanaannya tidak dianggap baik oleh Islam. Adat dalam bentuk ini dapat diterima dalam Islam, namun dalam pelaksanaan selanjutnya mengalami perubahan dan penyesuaian. Umpamanya tentang zhihar, yaitu ucapan suami yang menyamakan istrinya (punggungnya) dengan ibunya sendiri. Zhihar ini merupkana cara yang sudah biasa berlangsung dikalangan masyarakat Arab 
sebagai usaha suami untuk berpisah (bercerai) dengan istrinya. Sesudah suami melakukan zhihar, maka suami dan istrinya tidak diperbolehkan lagi berhubungan dan putuslah hubungan mereka sebagai suami istri. Islam menerima zhihar tersebut dengan perubahan, yaitu zhihar dinyatakan menyebabkan suami istri tidak boleh berhubungan kelamin, namun tidak memutuskan perkawinan. Bila keduanya akan berhubungan lagi, terlebih dahulu harus membayar kafarat (kewajiban agama akibat suatu pelanggaran).

3) Adat lama yang pada prinsipnya dan pelaksanaannya mengandung unsur mafsadat (merusak). Maksudnya, yang dikandungnya hanya unsur perusak dan tidak memiliki unsur manfaatnya, atau ada unsur manfaatnya tetapi unsur perusaknya lebih besar. Umpanya tentang berjudi, minum-minuman yang memabukkan dan praktik rentenir (membungakan uang secara riba). Adat dalam bentuk ini ditolak oleh Islam secara mutlak. Islam menetapkan ketentuan hukum yang berbeda dan berlawanan secara diametral dengan adat demikian yang biasa berlaku sebelum Islam datang.

4) Adat atau urf yang telah berlangsung lama, diterima oleh orang banyak karena tidak mengandung unsur mafsadat (perusak) dan tidak bertentangan dengan dalil syara yang datang kemudian, namun secara jelas belum terserap ke dalam syara baik secara langsung atau tidak langsung. Adat atau urf dalam bentuk ini jumlahnya banyak sekali dan menjadi perbincangan di kalangan ulama. Bagi kalangan ulama yang mengakuinya berlaku kaidah :

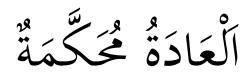

Artinya: "Adat itu dapat menjadi dasar hukum".

Selain rumusan hukum dalam Undang-undang Perkawinan tersebut, Pasal 113 sampai Pasal 162 KHI merumuskan garis hukum yang lebih rinci mengenai sebab-sebab terjadinya perceraian, tata cara, dan akibat hukumnya. Sebagai contoh Pasal 113 KHI sama dengan Pasal 38 Undang-Undang Perkawinan. Pasal 114 mengenai putusnya Perkawinan yang disebabkan oleh perceraian maka dapat terjadi karena talak atau berdasarkan gugatan perceraian. Pasal 115 KHI mempertegas bunyi Pasal 39 Undang-undang Perkawinan yang sesuai dengan konsern KHI, yaitu untuk orang Islam : perceraian hanya dapat dilakukan di depan sidang Pengadilan Agama setelah Pengadilan Agama tersebut berusaha dan tidak berhasil mendamaikan kedua belah pihak (Ali, 2007: 74)

Secara teori, peradilan agama dalam bentuknya yang sederhana telah ada sejak masuknya Islam ke Indonesia, dan kemuudian oleh pemerintah kolonial Belanda diakui dan dimantapkan kedudukannya. Pada Tahun 1820, melalui stbl Nomor 22 Pasal 13, dinyatakan bahwa para bupati wajib memperhatikan soal-soal agama Islam dan menjaga supaya 
para pemuka agama dapat melakukan tugas mereka sesuai dengan adat kebiasaan orang Jawa, seperti dalam soal perkawinan, pembagian pusaka, dan yang sejenis dengan itu. Dari istulah "Bupati" yang digunakan dalam instruksi pemerintah Hindia Belanda pada bulan September 1801 dan stbl. Nomor 22 Tahun 1820 tersebut, dapat diduga telah ada peradilan agama, paling tidak di seluruh Pulau Jawa. Pada tahun 1823, dengan resolusi Gubernur Jenderal Hindia Belanda Nomor 12 tanggal 3 Juni 1823, diresmikan Pengadilan Agama di Kota Palembang yang diketuai oleh Pangeran Penghulu, sedangkan Banding dapat dimintakan kepada Sultan. Wewenang Pengadilan Agama di Palembang itu meliputi (Jazuni, 2005: 376-377):

1) Perkawinan.

2) Perceraian.

3) Pembagian harta.

4) Kepada siapa anak diserahkan apabila orang tua bercerai.

5) Apakah hak tiap-tiap orang tua yang bercerai itu terhadap anak mereka.

6) Pusaka dan wasiat.

7) Perwalian, dan

8) Perkara-perkara yang lain yang menyangkut agama.

Dari penjelasan tersebut di atas, dapat dipahami bahwa ketentuan mengenai perceraian telah jelas di atur secara rinci di dalam ketentuan baik di dalam Undang-undang maupun dalam bentuk Instruksi Presiden Tahun 1991 yang berupa Kompilasi Hukum Islam (KHI). Dari peraturanperaturan tersebut dapat diambil simpulan bahwasannya proses perceraian antara suami dan istri ketika dihadapkan suatu persoalan rumah tangga harus dilakukan di depan sidang Pengadilan Agama khusus untuk orang-orang yang beragama Islam.

\section{SIMPULAN}

Keharusan perceraian dilakukan di depan sidang pengadilan agama ini sejalan dengan ketetapan syari'at Islam bahwa madharat haruslah dihilangkan, dan turunan dari qaidah tersebut apabila terjadi perbenturan antara maslahat dan madharat maka maslahat yang lebih diutamakan. Artinya tugas dan fungsi hakim pengadilan agama merupakan tugas suci, dan dalam hal perkara perceraian hakim pengadilan agama bertugas untuk mewujudkan kembali keluarga sakinah, mawaddah, dan rahmah. Perlu diketahui bahwa kehadiran pengadilan agama ini merupakan salah satu peradilan khusus yang untuk menangani perkara orang-orang beragama Islam.

Dalam hal perkara perceraian, hakim pengadilan agama memperhatikan betul alasan-alasan terjadinya perceraian sebagaimana 
terdapat dalam Peraturan Pemerintah No. 9 Tahun 1975 di dalam Pasal 19, dan tidak di dasari atas intervensi, ataupun hal-hal yang dapat mempengaruhi kualitas putusan yang akan dikeluarkannya. Karena Hakim Pengadilan Agama dalam memeriksa perkara berpegang teguh kepada asas atau prinsip sebagaimana terdapat di dalam Undang-Undang No. 7 Tahun 1989 Jo Undang-Undang No. 3 Tahun 2006 Jo UndangUndang No. 50 Tahun 2009 tentang Peradilan Agama. Undang-Undang No. 48 Tahun 2009 tentang Kekuasaan Kehakiman. Undang-Undang No. 1 Tahun 1974 Jo Undang-Undang No. 16 Tahun 2019 tentang Perkawinan, maupun Peraturan Pemerintah No. 9 Tahun 1975 tentang Pelaksanaan Undang-Undang No. 1 Tahun 1974 tentang Perkawinan.

\section{DAFTAR PUSTAKA}

\section{Buku-buku}

Abdul Manan. Aneka Masalah Hukum Perdata Islam di Indonesia. Jakarta: Kencana Prenada Media Group, 2008.

Ali, Z. Hukum Perdata Islam di Indonesia. Yogyakarta: Sinar Grafika Offset. 2007.

Anwar, M. Fiqih Islam "Muamalah, Munakahat, Faro'id E Jinayah" (Hukum Perdata \& Pidana Islam Beserta Kaedah-kaedah Hukumnya). Bandung: Al Ma'arif Percetakan Offset, 1988.

Asshiddiqie, J. Perihal Undang-undang. Jakarta: Raja Grafindo Persada, 2010.

Bek, S. M. K. Sejarah Hukum Islam. Bandung: Nuansa Aulia, 2009.

Djamal, A. Hukum Islam (Asas-asas, Hukum Islam I, Hukum Islam II). Jakarta: Mandar Maju, 1992.

Hakim, R. Hukum Perkawinan Islam (Untuk UIN, STAIN, PTAIS). Bandung: Pustaka Setia, 2000.

Husaini, I. T. A. B. B. M. Al. Kifayatul Akhyar (Kelengkapan Orang Saleh) (Diterjemah). Bogor: Bina Iman, 1993.

Jazuni. Legislasi Hukum Islam di Indonesia. Bandung: Citra Aditya Bakti, 2005.

Muhammad, A. K. Hukum Perdata Indonesia. Bandung: Citra Aditya Bakti, 2010.

Muhammad Jawad Mughniyah. Figh Lima Madzhab. surabaya: Lentera, 2011.

Rasjid, S. Fiqih Islam. Bandung: Sinar Baru Algensindo, 2011.

Sabiq, Sayyid. Fikih Sunnah. Bandung: Al-Ma'arif, 1990.

Sugiyono. Metode Penelitian Kuantitatif Kualitatif dan RED. Bandung: 
Alfabeta, 2014.

Suharismi. Prosedur Penelitian (Suatu Pendekatan Praktik). Jakarta: Rineka Cipta, 2013.

Summa, M. A. Hukum Keluarga Islam di Dunia Islam. Yogyakarta: Raja Grafindo Persada, 2004.

Syahuri, T. Legislasi Hukum Perkawinan di Indonesia (Pro Kontra Pembentukannya Hingga Putusan Mahkamah Konstitusi). Jakarta: Kencana Prenada Media Group, 2013.

Syarifudin, A. Ushul Figh. Jakarta: Kencana Prenada Media Group, 2008.

Syarifudin, A. Hukum Perkawinan Islam di Indonesia (Antara Figh Munakahat dan Undang-undang Perkawinan). Jakarta: Prenada Media Grup, 2009.

Tutik, T. Hukum Perdata dalam Sistem Hukum Nasional. Jakarta: Prenada Media Grup, 2008.

Usman, R. Aspek-Aspek Hukum Perorangan dan Kekeluargaan di Indonesia. Yogyakarta: Sinar Grafika Offset, 2006.

\section{Jurnal -Jurnal}

Abdurrahman Konoras, Telaah Tingginya Perceraian di Sulawesi Utara (Studi Kasus Putusan Pengadilan Agama. LPPM Bidang EkoSoBudkum, 1, 2014.

Siregar, R. S. Dampak Perceraian yang Tidak Sesuai Dengan Prosedur Perundang-Undangan. Fitrah, 1 (1), 2015.

Sadiani, A. K. Analisis Kritis Pemikiran Wahbah az Zuhaili tentang Penetapan Talak. Venomena, 8 (2), 2016.

Reza Pahlevi Nurpaiz, Syaik Abdillah, Dahwadin, Hasanudin, D. R. M. Kedudukan Isteri Bekerja Dalam Mengurus Keluarga Perspektif Hukum Islam Reza Fahlevi Nurpaiz, Syaik Abdillah, Dahwadin , Hasanudin, Dwi Reiza Meinanti STISNU Tangerang Pendahuluan Perkawinan ialah akad yang menghalalkan pergaulan antara seorang laki-la. Mutawasith, 3 (1), 2020. 
Dahwadin, et al.

Halaman ini sengaja dikosongkan 